\title{
The Impact of Balanced Scorecard on Performance: The Case of Vietnamese Commercial Banks
}

\author{
Tran Trung TUAN ${ }^{1}$
}

Received: September 28, 2019 Revised: November 01, 2019 Accepted: November 15, 2019

\begin{abstract}
Balanced Scorecard (BSC) is one of basic contents of managerial accounting. Balanced Scorecard (BSC) will help the manager to measure and evaluate the operating performance in enterprises. Therefore, providing the theory base as well as in fact with regards to apply with Balanced Scorecard, impact of applying with Balanced Scorecard on the performance of company, from then providing for the managers with the base to promote on applying the Balanced Scorecard in Vietnamese Enterprises aimed to improve the operating performance of enterprises meaningfully and neccessary. However, balanced scorecard in general is a very new content in both theoretical and practice in Viet Nam. The study aims to explore the application with Balanced Scorecard in enterprises according to 4 perspective of Balanced Scorecard in Vietnamese commercial banks. In the dimension of this paper, SPSS 22 was used to collect and analysis data, basing on the results of 109 questionnaires of managers and head of department from Vietnamese commercial banks. Research have shown impact of Balanced Scorecard on the performance of Vietnamese commercial banks. This is the scientific basis for enterprises of Vietnam in general and Vietnamese commercial banks firms in particular have a successful application of balanced scorecard to improve the business performance.
\end{abstract}

Keywords : Balanced Scorecard, Commercial Banks, Managerial Accounting, Operating Performance, Financial Perspective, Vietnam

JEL Classification Code : M40, M41, M42

\section{Introduction}

Balanced Scorecard (BSC) is to measure the operating performance in both financial perspective and non-financial perspective, to support for the Enterprises to define their vision and strategy and changing their vision and strategy into the particular activities, implementing to measure accurately, comprehensively, providing the information accurately, correctly for the manager in making the business decision. Balanced Scorecard (BSC) in addition to measure the traditional achievement with 3 other perspectives

1 First Author and Corresponding Author, Lecturer, School of Accounting and Auditing, National Economics University, Hanoi, Vietnam. [Postal Address: No.19, 57 Alley, 281 Lane, Truong Dinh Street, Tuong Mai Ward, Hoang Mai District, Ha Noi, 100000, Viet Nam] Email: trungtuanktqd@gmail.com

(c) Copyright: Korean Distribution Science Association (KODISA)

This is an Open Access article distributed under the terms of the Creative Commons Attribution Non-Commercial License (http://Creativecommons.org/licenses/by-nc/4.0/) which permits unrestricted noncommercial use, distribution, and reproduction in any medium, provided the original work is properly cited. including: Perspective of customers, perspective of internal procedure, perspective of learning and development. Four perspectives of BSC enable the enterprises to define and balance comprehensively the perspectives of business administration. That is a balance between long term target and short term targets, between the external standards and internal standards of enterprises, between the desired structure and fact result, satisfaction of elements will support for enterprises to develop stably in wide and deep integrated economy and violently competitiveness at present. BSC is able to provide the focused point to support for the company to concentrate and effort in such points, defining and communicating the problems priority to the manager, employee, investor and customers.

Measuring and evaluating the impact performance of parts, individuals as well as all enterprises is becoming one of the most difficult and important at present of enterprises. Balanced Scorecard (BSC) will provide the accurate information of enterprises in controlling and reducing the unnecessary expenses. As the Balanced Scorecard (BSC) is 
used in the enterprises will support for measuring and evaluating the activities happening accurately and comprehensively as well as improving the operating performance of parts as well as all enterprises. If arisen with the expenses in excess of anticipation, the manager will find out the cause and neccessary methods of overcoming. From then it will reduce the expenses, increse the revenue and performance of using the capital and will improve the operating performance of enterprises. However in Vietnam, topic on Balanced Scorecard in Enterprises are regarded as new in consideration of both theory and practice. This Research have shown the impact of applying Balanced Scorecard on the performance of Vietnamese commercial banks.

\section{Literature Review}

\subsection{Conceptual Framework of Balanced Scorecard}

Balanced ScoreCard (BSC) is a system of measurement and making a plan of modern strategy, introduced by Kaplan and Norton (1992) for the first time in 1992. Balanced ScoreCard is a method of making plan measuring the task performance to convert the vision and general strategy of organization, enterprise into the specific target with the measurements and specific targets. The Balanced Scorecard (BSC) was originally a one-year multi-company study. This is a tool of giving prominence on performance measuring rule and generalizing the core activities of units such as: Customer, process of internal profession, training and developing the staff and interest of shareholders (Kaplan \& Norton, 1992).

There are limitations of business performance observing target system based on the financial targets and necessity to supplement the non-financial goals in the system of evaluation. Researching the proposal to build the target system of evaluating the business performance according to the model of BSC including the financial goals and nonfinancial goals connected with each other according to the relationship of cause and result to describe the strategies to become the operating targets specifically in many aspects: Finance, customer, internal business procedure, training and development (Kaplan \& Norton, 1996a). In the target system of evaluating the business performance of Enterprises that is necessary to contain the reflecting targets on factors has important influence on successful performance of strategy. Elements have important influence on successful performance of strategy including: the quality of staff, internal business procedure, satisfaction of customers...The system on evaluating the business performance including the financial goals and non-financial goals have an influence on successful performance of business strategy of enterprises connected together according to the cause and result relationship of BSC (Kaplan \& Norton, 2001).

The Balanced Scorecard Strategic Management System is comprised of "a core principles framework and processes that interpret an organization's mission and strategy into a comprehensive set of performance measures strategically aligned with creativities" (Inamdar, Kaplan, \& Reynolds, 2002). A vital aspect of the BSC is the articulation of linkages between performance measure and strategic objective (Banker, Janakiraman, \& Konstanz, 2001). Once linkages are understood, strategic objectives can be further translated into actionable measures to help organizations improve performance (Kaplan \& Norton, 2001). Balanced Scorecard includes a financial perspective that communicate the effects of actions already taken. It supplements the financial measures with operational measures on customer satisfaction, internal business processes, and the learning and growth and commercial banks activities- operational rules that are the drivers of future financial performance (Kaplan \& Norton, 1992)

The first generation of BSC has just included 4 aspects with the measuring rules to measure performance. However, these aspects have not stated on the relationship of cause and effect. To the second generation of BSC has built a relationship of cause and effect among the aspects with one another. Not only stop there, but the third generation of BSC has linked the rules in 4 aspects of BSC with the enterprise's strategy. Through the process of development, BSC has completed and really become an useful management tool of managers (Cobbold, Lawrie, \& Issa, 2004). Traditional financial goals such as profit, ROI, ROE...are defined on the basis of operating result happened, so these targets will not predict on the enterprises. Meanwhile, business activities of Enterprise has achieved a high performance as the Enterprise has a combination among the elements happened and elements have predicted features (Samir Ghosh, 2006). A great number of manufactured companies in Malaysia have still focused on the financial measuring rules more than non -financial measuring rules (Jusoh \& Parnell, 2008)

In addition to the researches on BSC in Enterprises generally, there are also researches on application of BSC in specific business sectors. Ferenc (2011) has provided the model on evaluating the company performance in 4 aspects: Finance, Customer, Internal Process, Training and Development (Ferenc, 2011). Kartalis, Velentzas and Broni (2013) researched the application of BSC in the industrial companies in Greece. Research has been carried out by means of structure interview questions, semi-structure and carried out an interview on the chief accountant and management board of company. Researching results showed that, industrial companies in Greece have applied with BSC as a system of measuring rule to evaluate the operating performance with four aspects. In the banking sector, there have been also researches on BSC in evaluating the performance. Moufty (2009) has discovered the role of Balanced Scorecard in UK banks. The research has also showed the act of manager in process of using the Balanced Scorecard in management at the banks. Irrational points of traditional measurement system and necessity to apply with new measuring system as Balanced Scorecard (Moufty, 
2009).

Al-Najjar and Kalaf (2012) used the data in Iraqi bank in the period of 2006-2009, aimed to analyze the aspects of Balanced Scorecard and the relationship of cause and effect with the strategy of bank (Al-Najjar \& Kalaf, 2012). Targets of balanced scorecard aspect are used for the research banks by means of generalizing the researches in previous time. Research showed the system of expenditure related to the aspects of balanced score card used in the banks (Balkovskaya \& Filneva, 2016). Abofaied (2017) studied how balanced score card has been applied and developed in Libya banks by means of using the concepts and content in balanced score card of Kaplan and Norton and using data in the banks from 2007-2010. Research has analyzed the relationship of cause and effect, used the financial aspects and non-financial aspects (Abofaied, 2017).

\subsection{Balanced Scorecard Perspectives}

Balanced Scorecard (BSC) is a modern system of measuring the performance, Comprehensive focus is on measuring both the financial and non-financial Perspectives, helping enterprises to identify their vision and strategy and transforming vision and strategy into specific activities. Balanced Scorecard added the traditional achievement measurement system with 3 other Perspectives including: Customers, Internal Business Process, Learning and Growth (Kaplan \& Norton, 1992). By that way, Balanced ScoreCard help enterprise to ensure a balance in measuring final business performance, behavioral orientation and performance results of all organizations and individuals in organization towards common goals and sustainable development of organization. The balanced scorecard has four perspectives that help the manager to reorganize their vision and strategy with organizations activities and processes genuine for organizational performance against preset goals (Kaplan \& Norton, 1992).

\subsection{Financial Perspective}

Financial perspective is seen as a past factor in the chain, it describes the process of implementation with the measurement of traditional calculations of interest, asset statistics and the increase in profits. Expectations are related to the shareholders. The BSC model starts with financial goals and interpretation, which is the financial driving force of the long-term sustainable value creation process. In the aspect of finance, in the BSC model, there are additional measures such as general income from operations, increased economic value, and revenue on rented capital. Increasing the revenue with a measure to achieve the target of existing customer value raise, expanding the revenue-creating the opportunities...(Kaplan \& Norton, 1996a). In a Balanced Scorecard, the financial goal must be connected with the business strategy, which represents the financial results of the strategy: revenue, profit, total assets, outstanding debt, bad debt rate.
Depending on the business sector and the specific characteristics of enterprises, appropriate financial indicators should be developed. For the banking sector, important financial indicators are total assets, outstanding loans, bad debt rate, overdue debt rate, pre-tax profit, after-tax profit ...The financial perspective deals with those issues through which an organization can generate economic growth in shareholder value and calculates the profitability constituent of the strategy. It represents the long- term goal of the organizations to provide superior returns established on the capital endowed with the unit (Kaplan \& Norton, 1996b). Sureshchandar, Rajendran and Anantharaman (2002) state that every business exists in order to make profits financial perspective performance provides the ultimate definition of an organization's success. Thus the financial perspective, therefore, reflects an organization's output criteria and should include both monetary measures and the idea of value creation.

\subsection{Customer Perspective}

BSC emphasizes the chain link between products and customer satisfaction on those products. Value propositions are attributes of products and services that aim at customer satisfaction. Many organizations have a corporate mission that focuses on customers. Therefore, a company's performance from its customers' perspective has become a priority for top management (Kaplan and Norton, 1992). The attributes of products and services describe the usefulness of products - functionality, quality and timeliness - in relationship with prices. Customer relationship attributes include the elements of service, convenience, and quick response. Image attributes and reputation include invisible factors that attract customers to the company, how these attributes describe the company in the eyes of customers by means of advertising, professional qualification for the process of carrying out (Kaplan \& Norton, 1996a).

Typical measures of customer value outcomes are market share, customer acquisition, customer retention, customer profitability and customer satisfaction. Indicators of measurement, Aspect of customer is the indicator showing the relationship between Customer satisfaction and operating result of enterprise: Customer satisfaction, Customer loyalty, market share, the number of new customers is increased, the number of old customers is unchanged, the number of customers is lost, feedback rate of customers...(Kaplan \& Norton, 1996b). Customer perspective describes the value proposal that the organization will apply to please customers and, therefore, generate more sales to the most desired customer groups. The measures selected for the perspective should measure both the value delivered to the customer and the assumptions that come as a result of the significance proposal (Jensen, 2001). Selecting measures for the Customer Perspective of the Balanced Scorecard depends on the type of customers preferred and the value that the organization provides to them (Niven, 2002). 


\subsection{Internal Business Process Perspective}

The third Perspective of BSC is the Internal Business Process, which is interested in the levels of implementation. Internal process measurement describes the performance in distributing the value to customers. It can include both shortterm and long-term objectives (Kaplan \& Norton, 1996c). (Kaplan \& Norton, 1996a) has recommended the internal value chain model to divide into four main groups: process improvement, operational process, customer management process, and social process management. The social processes management is related to safe working environment, health of employees and social-related activities. Measuring the process has stated the clauses of time, quality and expense of additional materials (Kaplan \& Norton, 1996a). This is the most critical perspective for the success of an organization. It includes internal business processes that ensure the highest quality of products and services (Pandey, 2005).

BSC also recognizes the strong relationship between business processes and customers. Quality issues, cost and timely nature are very important when they serve for a customer satisfaction. This perspective focuses on all the activities, and key processes required for the organization to excel at providing the value projected by the customers both efficiently and productively (Johnsen, 2001). Aspects of internal processes: In order to achieve the financial goals of enterprise and meet the expectations of the customers, the enterprises must define the most excellent and critical business processes. The key process is monitored to ensure that results achieved are satisfactory. The measurement of internal processes includes criteria such as: Loss amount found out prior to delivery, total quantity of products is remade or total of discarded scrap when produced... This perspective entails the procedures that an organization must develop and master to be popular. Some organizations will target on such elements as order processing, delivery, manufacturing, and product development as examples (Niven, 2002).

\subsection{Learning and Growth Perspective}

The fourth Perspective of Balanced Scorecard is Learning and Growth. The measurement of Learning and Growth describes the sustainable investment for future. This aspect concerns the professional development of employees, the spirit of attaching to the Enterprise and the opportunities to improve skills. Kaplan and Norton have categorized their learning and development into three major categories (Kaplan \& Norton, 1996a). Staff's ability, Capability of information system, improving, handing over authority and connection. Kaplan and Norton (1992) advocate that organizations are required to introduce continual improvements to their existing products and processes and gain the ability to set up the entirely new product with expanded capabilities.
As the foundation of any strategy, this perspective is concerned with the intangible assets of an organization, mainly with the internal skills and capabilities that are required to support the value-creating internal processes (Johnsen, 2001). The primary focus of this perspective was laid on investing for future such as new equipment and product research and development (Kaplan \& Norton, 1996b). Indicators of training and development show the organization's investment in human resources, which is a premise for sustainable development in future. This aspect is also a support factor for achieving results in three remaining aspects. The contents of this aspect are indicators such as: employee participation in the organization's training programs, employee satisfaction, the number of trained employees, and compliance with the regulations of organization... Niven (2002) suggested that depending on the desired employee skills and actual employee skills, some of the organizations altered their job descriptions, transfer employees to other divisions, and/or implement incentive databases, planned to motivate employees to deliver suggestions, obtain education or training, and/or gain tenure through constant employment.

\subsection{Impact of Balanced Scorecard on Organizational Performance}

In order to be able to make an accurate decision, managers in enterprises in general and commercial banks in particular need to have accurate information, including the financial and non-financial information. Kaplan and Norton (1996a) suggest that all improvements in the non-financial areas after the BSC implementation should be eventually linked to economic performance; based on their findings, it usually takes two, three years for the breakthrough performance to be achieved (Kaplan \& Norton, 1996c). Applying a Balanced Scorecard will help the managers to evaluate the performance of enterprises accurately and comprehensively. This will help enterprises to reduce costs, increase revenue and improve business performance. There are many authors with the results of their research affirmed this judgement as pointed out that is non- financial performance measures are positively associated with performance (Abernethy \& Lillis, 1995; Chenhall, 1997; Ittner \& Larcker, 1997; Ittner \& Larcker, 1995; Ittner, Larcker, \& Meyer, 2003). They suggested that organizations adopting performance measurement system would improve their profitability and corporate performance by identifying the pivotal relationships between actions and performance (Buhovac \& Slapnicar, 2007).

Applying a modern performance measuring system like BSC widely, especially used for financial and non-financial indicators will increase the performance of enterprises (Stede, Chow, \& Lin, 2006). Braam and Nijssen (2004) believed that when the enterprises apply a performance evaluation system including the financial and non-financial indicators, it will be more effective but the enterprises along with the conditions just apply the financial indicators to 
evaluate the performance. Zahirul and Wendy (2000) showed that when applying with BSC, BSC's effect on business performance can be found out clearly.

According to Kaplan and Norton (1992, 2001), it is believed that applying an effective evaluation system with many aspects will change the business environment of enterprise and change the results of enterprise. To manage the enterprise effectively, BSC is considered as a strategic management tool to improve the performance of enterprises (Johnsen, 2001; Kaplan \& Norton, 2001; Brignall, Fitzgerald, Johnston, \& Silvestro, 1991). BSC usage is positively and significantly correlated with organizational performance (Zahirul \& Wendy, 2000). Using BSC has led to positively influences overall company performance" (Braam \& Nijssen, 2004). One reason for the general statements mentioned above can be that, except for Braam and Nijssen (2004), all studies had the topic of BSC's effects on performance as a secondary or coequal one "Use of BSC has led to better results". According to the study of Braam and Nijssen (2004), Balanced Scorecard practice will not automatically improve organization performance, but that the manner of its use matters: Balanced Scorecard use that complements corporate strategy positively influences organizations performance, while Balanced Scorecard use that is not associated with the approach may decrease it.

\section{Research Methodology}

\subsection{Research Model}

Research using quantitative research method to determine the impact of the Balanced Scorecard on the operation of Vietnamese Commercial Banks. The model can be generalized as follows:

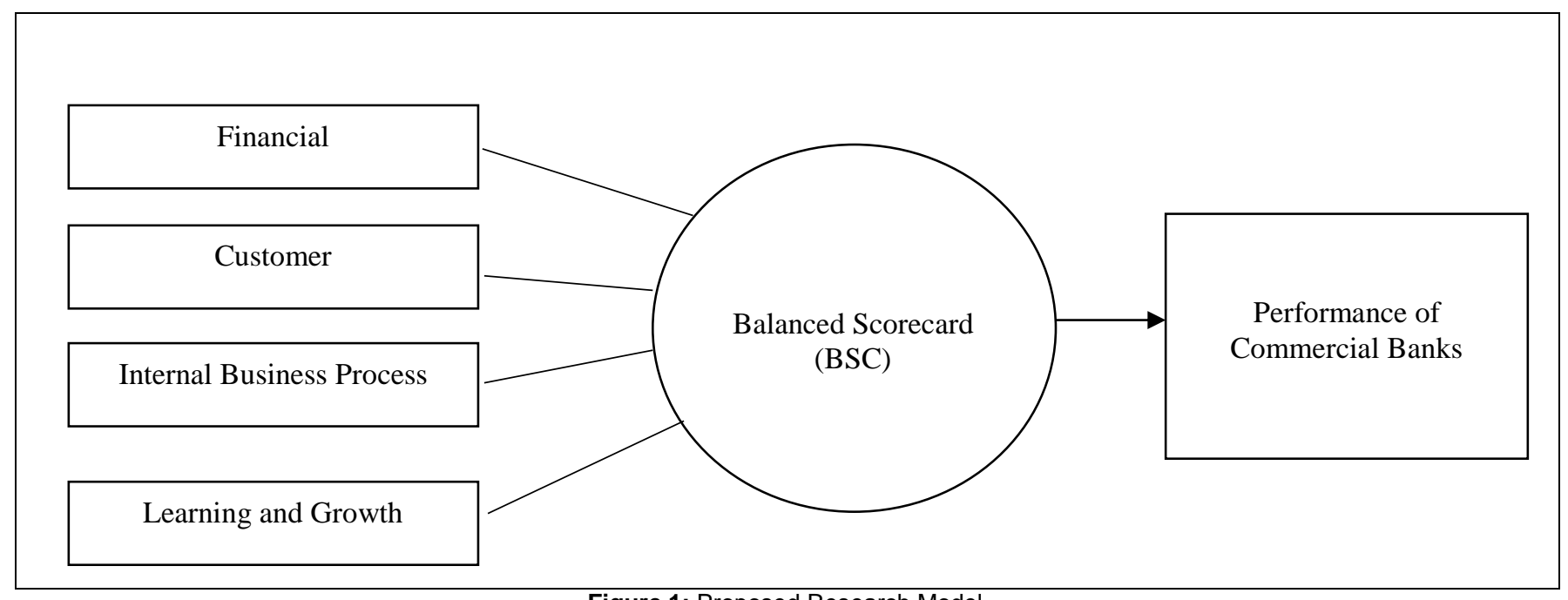

Figure 1: Proposed Research Model

\subsection{Hypothesis}

From the Literature Review result given, there were 4 hypothesis used to assess the impact of the Balanced Scorecard on the operation of Vietnamese Commercial Banks:

H1: There is significant relationship between Financial Perspective of Balanced Scorecard and Performance of Vietnam Commercial Banks.

H2: There is significant relationship between Customer Perspective of Balanced Scorecard and Performance of Vietnam Commercial Banks.

H3: There is significant relationship between Internal Business Process Perspective of Balanced Scorecard and Performance of Vietnam Commercial Banks.
H4: There is significant relationship between Learning and Growth Perspective of Balanced Scorecard and Performance of Vietnam Commercial Banks.

Next, the research will design the questionnaires and collect data by means of surveys with different levels and send them to managers in Vietnamese commercial banks; thereby synthesizing and analyzing data using the SPSS 22 statistical software to evaluate the application of Balanced Scorecard and run the model to build the equation to determine the impact level of Balanced Scorecard equal to the operation of Vietnamese commercial banks. The equation of the study is expected as follows:

$$
Y=\alpha+\beta 1 * X 1+\beta 2 * X 2+\beta 3 * X 3+\beta 4 * X 4+\varepsilon
$$

In which of:

+ Y: Performance of Commercial Banks

$+\mathrm{X} 1$ : Financial Perspective 
$+\mathrm{X}$ : Customer Perspective

$+\mathrm{X}$ : Internal Business Process Perspective

$+\mathrm{X} 4$ : Learning and Growth Perspective

$+\varepsilon$ : Random error

\subsection{Scale of Variables}

\subsubsection{Application of the Balanced Scorecard}

Balanced Scorecard is based on 4 Perspectives: Financial Perspective, customer Perspective, Internal Business Process Perspective, Learning and Growth Perspective. There are many researchers in different countries, different fields to research the application of balance points in different fields such as: (Abofaied, 2017)

Financial Perspective: Debt recovery results of customers, ROI, ROE, Profit Margin, Property quality

Customer Perspective: Customer Satisfaction, Customers Growth, Growth of Current Accounts, Growth of Saving Accounts, The growth in the number of customers using modern distribution channels (e-banking, card...)

Internal Business Process Perspective: Productivity Growth, Growth of Banking Services, Credit Growth, Growth in Software Application, Front Office Employees Growth

Learning and Growth Perspective: The rate of recommendations made, Employee Turnover, Number of trained Employees, Employee Participation in Development Programs, Number of violations of bank regulations.

\subsubsection{Performance of Enterprises}

Performance of Commercial Banks are measured by 5 observed variables of results and efficiency of enterprises, including: Return on Investment (ROI), Gross profit, Employee turnover, and customer satisfaction. The growth of banking services; This scale is used by (Zahirul \& Wendy, 2000) in their research based on the theory of Balanced Scorecards used by many authors in their researches .... The interviewees will be asked on the performance of their enterprises by comparing their performance with direct competitors or based on industry averages or other enterprises with the same scale on the measuring scale of Likert from $1=$ Poor to $5=$ very good.

\subsection{Samples}

Until 2019 Vietnam has 35 commercial banks. From the overall study of 35 banks, the author will select the banks that have implemented the application of the Balanced Scorecard or the perspective of Balanced Scorecard in evaluating the performance and results. The responsibility centers are headed by the managers in enterprise and are responsible for managing all operations of responsibility centers, so as to evaluate the results and performance, research in the world and domestic Balanced Scorecard has collected information from managers in the bank including: members in the board of directors, board of directors, heads of departments, transaction offices, bank branches ...
This data collection method has been implemented by many domestic and foreign Balanced Scorecard Researchers.

\subsection{Method of Gathering and Analyzing Data}

Research using the quantitative research methods based on previous researches on the Balanced Scorecards. The author conducts the surveys at Vietnamese Commercial Banks. Depending on the characteristics and ability to collect the answer sheets of each bank, the research has sent an average of 10 survey papers to each Vietnamese Commercial Bank with management positions such as: Members of Management Board, The board of directors, the deputy heads of departments, transaction offices, bank branches ... The questionnaires will be interviewed directly by the author, the interviewers or by the system of Google investigation forms, call or send the express mail ...Data collected from questionnaires will be analyzed by specialized SPSS data analysis software. The research will use the SPSS 22 software to support for descriptive statistics, frequency analysis, verification, Anova analysis, regression.

\section{Research Results and Discussion}

Through many researches and preliminary surveys in the past, the experienced management accounting researchers realized that more than half of the participators were the leaders of Vietnam Commercial Banks. There were 210 survey forms sent to 21 Commercial Banks throughout the country and received 117 in returns from 15 Commercial Banks. After removing 08 invalid results, there were 109 remained and to be used to analysis. The final results will be mentioned in the following sections of the study.

\subsection{Cronbach's Alpha Measure}

The collected data will be imported to SPSS 22 application with 20-scale checking of Cronbach's Alpha. So, the research showed that Cronbach's Alpha score $=0.927$ (greater than 0.7 ) and all of the 20 variables were consistency satisfied. Moreover, from the result of ItemTotal Statistics, we would keep all of the 20 variables without any elimination. For 5 variables of performance, The Cronbach's Alpha score $=0.942$ (greater than 0.7) and this meant all of the 5 variables were consistency satisfied. Moreover, from the results of Item-Total Statistics, we would keep all of the 5 observation variables. Eventually, by inspection of Balanced ScoreCard and scale of performance, we could realize that all of the measurement scales were suitable, consistent and having the statistic meanings in analysis of Vietnam Commercial Banks.

\subsection{Factor Analysis}

Using Maximum Likelihood method, the results were 
given, there were 4 factors collected, described of $86.42 \%$ of the data variation. By Bartlett's Test, we had P-value $=0.000$ $<0.05$ and KMO Test gave the result of $0.873>0.5$, these meant the variables were mutually related in statistics. After that, when rotating the elements by Promax measure, we collected 4 of Balanced ScoreCard factors, including: Financial, Customer, Internal Processes, Learning and Growth. There are 4 factors were described. For the Business Performance Variance, there were 5 observation variables. By factor analysis, we concluded 01 factor called performance, described $81.26 \%$ of data variations. By Barlett's Test which gave P-value $=0.000<0.05$ and KMO Test $=0.672>0.5$, these mean the variables were mutually related in statistics. Eventually, the result of factor analysis showed that there were 01 business performance variance and 4 others expressing 4 factors of Balanced ScoreCard with high consistency in statistics.

\subsection{The Impact of the Balanced ScoreCard on Performance}

To analyze the impact of the Balanced ScoreCard to the performance of the enterprise, the study used a multiple regression model Multiple Linear Regression (MLR), results of the analysis are as follows:

Table 1: Model Summary ${ }^{\mathrm{b}}$

\begin{tabular}{|c|c|c|c|c|c|c|c|c|c|}
\hline \multirow[b]{2}{*}{$\mathbf{R}$} & \multirow[b]{2}{*}{ R Square } & \multirow{2}{*}{$\begin{array}{l}\text { Adjusted R } \\
\text { Square }\end{array}$} & \multirow{2}{*}{$\begin{array}{l}\text { Std. Error of } \\
\text { the Estimate }\end{array}$} & \multicolumn{5}{|c|}{ Change Statistics } & \multirow[b]{2}{*}{ Durbin-Watson } \\
\hline & & & & $\begin{array}{c}\text { R Square } \\
\text { Change }\end{array}$ & F Change & df1 & df2 & $\begin{array}{c}\text { Sig. F } \\
\text { Change }\end{array}$ & \\
\hline, $733^{\mathrm{a}}$ & ,537 & ,519 & ,75995 &, 537 & 30,172 & 4 & 104 &, 000 & 1,913 \\
\hline
\end{tabular}

$\mathrm{R} 2=0.537$, meaning that $53,7 \%$ of the operational differences observed was explained by change of variables in the model and linear regression models were constructed in accordance with the data set up to 53,7\%. Durbin-Watson value $=1.913$ approximate to 2 , that meant no autocorrelation superlative chain.

Table 2: ANOVA $^{\mathrm{a}}$

\begin{tabular}{|cl|c|c|c|c|c|}
\hline Model & Sum of Squares & df & Mean Square & F & Sig. \\
\hline 1 & Regression & 69,699 & 4 & 17,425 & 30,172 \\
\\
Residual & 60,062 & 104 &, 578 & \\
& Total & 129,761 & $1000^{b}$ & \\
\end{tabular}

The analytical results show that the model built with statistical meaning by testing $\mathrm{F}=30.172, \mathrm{P}$-value $=0.000$
$<0.05$, reject the null hypothesis $\mathrm{Ho}: \beta \mathrm{j}=0$, the model developed in accordance with the general.

Table 3: Coefficients ${ }^{\mathrm{a}}$

\begin{tabular}{|c|c|c|c|c|c|c|c|c|}
\hline & \multirow{2}{*}{ Model } & \multicolumn{2}{|c|}{$\begin{array}{l}\text { Unstandardized } \\
\text { Coefficients }\end{array}$} & \multirow{2}{*}{$\begin{array}{c}\begin{array}{c}\text { Standardized } \\
\text { Coefficients }\end{array} \\
\text { Beta }\end{array}$} & \multirow{2}{*}{$t$} & \multirow{2}{*}{ Sig. } & \multicolumn{2}{|c|}{ Collinearity Statistics } \\
\hline & & B & Std. Error & & & & Tolerance & VIF \\
\hline \multirow[t]{4}{*}{1} & (Constant) & ,254 & ,321 & & ,792 & ,030 & & \\
\hline & $\mathrm{X} 2$ & ,260 & ,067 & ,279 & 3,903 &, 000 & ,868 & 1,152 \\
\hline & X3 & ,231 &, 065 & ,260 & 3,533 &, 001 & ,821 & 1,217 \\
\hline & $\mathrm{X} 4$ & 241 & .070 & 255 & 3,444 & 001 & 812 & 1,231 \\
\hline
\end{tabular}

Researchers such as Hair, Tatham and Black (1998) have said that VIF >10 will occur multicollinearity. The independent variables in the model are VIF $<10$ should satisfy the condition of multicollinearity. The model coefficients $\beta \mathrm{j}$ are $\mathrm{p}$-value is $<0.05$, which means that disprove the hypothesis $\mathrm{Ho}: \beta \mathrm{j}=0$. Thus, this model is appropriate. Thus, the regression model would be:

\section{$Y=0,254+0,280 * X 1+0,231 * X 2+0,260 * X 3+0,241 * X 4$}

Thus, through the above regression model can be seen that the aspects of Balanced ScoreCard are affected codirectionally with the performance of the business, which means that if the more we applied the aspects of Balanced ScoreCard, the higher of the performance of the higher business will be and vice versa statistically.

\section{Conclusions}

Balanced Scorecard is an advanced management tool that supports for the organizations to transform vision and strategy into short-term and long-term targets and specific measuring rules. This is a comprehensive solution for measuring and evaluating the operating aspects of an organization. Vietnamese Commercial Banks have researched and applied the Balanced Scorecard System. The research results have also shown that Balanced Scorecard is a new management tool recommended by Vietnamese Commercial Banks and has a good effect on the 
performance of Vietnamese Commercial Banks. The implementation of recommendations is to promote the application of this management tool in order to improve the performance of Vietnamese Commercial Banks is extremely necessary, especially in the background of Vietnamese Commercial Banks are integrating strongly as currently.

\section{References}

Abernethy, M. A., \& Lillis, A. M. (1995). The impact of manufacturing flexibility on management control system design. Accounting, Organizations and Society, 20(4), 241-258. doi: http://dx.doi.org/10.1016/03613682(94)E0014-L

Abofaied, A. (2017). Evaluation of bank's performance by using balanced score card: Practical study in Libyan environment. International Journal of Business and Management, 5(1), 1-14.

Al-Najjar, S. M., \& Kalaf, K. H. (2012). Designing a balanced scorecard to measure a bank's performance: A case study. International Journal of Business Administration, 3(4), 44-53.

Balkovskaya, D., \& Filneva, L. (2016). The use of the balanced scorecard in bank strategic management. Journal Business Excellence, 9(1), 48-66.

Banker, R. D., Janakiraman, S., \& Konstanz, C. (2001). Balanced scorecard: Linking strategy to performance. Morristown, NJ: Financial Executive Research Foundation.

Braam, G. J. M., \& Nijssen, E. J. (2004). Performance effects of using the balanced scorecard: A note on the Dutch experience. Long Range Planning, 37, 335-349.

Buhovac, A. R., \& Slapnicar, S. (2007). The role of balanced, strategic, cascaded and aligned performance measurement in enhancing firm performance. Economic and Business Review for Central and South- Eastern Europe, 9(1), 47- 74.

Cobbold, I., Lawrie, G., \& Issa, K. (2004). Designing a strategic management system using the third-generation balanced scorecard: A case study. International Journal of Productivity and Performance Management, 53(7), 624-633.

Chenhall, R. H. (1997). Reliance on manufacturing performance measures, total quality management, and organizational performance. Management Accounting Research, 8, 187- 206.

Ittner, C. D., \& Larcker, D. F. (1997). Quality strategy, strategic control systems, and organizational performance. Accounting, Organizations and Society, 22(3-4), 293-314.

Ferenc, A. (2011). Balanced score card measurement applications at a car manufacturer supplier company. 7th Research/Expert Conference with International Participations, "quality 2011". Neum, B\&H, June 01-04, 2011. (pp.85-90).
Ghosh, S. M. (2006). Measurement of corporate performance through balanced scorecard: An overview. Vidyasagar University Journal of Commerce, 11, 60-70.

Hair Jr., J. F., Tatham, R. L., \& Black, W. C. (1998). Multivariate data analysis (5th edition). Englewood Cliffs, NJ: Prentice -Hall International.

Inamdar, N., Kaplan, R. S., \& Reynolds, K. (2002). Applying the balanced scorecard in healthcare provider organizations/Practitioner's response. Journal of Healthcare Management, 47(3), 179-195.

Ittner, C. D., \& Larcker, D. F. (1995). Total quality management and the choice of information and reward systems. Journal of Accounting Research, 33(1995), 134.

Ittner, C. D., Larcker, D. F., \& Meyer, M. W. (2003). Subjectivity and the weighting of performance measures: Evidence from a balanced scorecard. The Accounting Review, 78(3), 725- 758.

Jensen, M. C. (2001). Value maximization, stakeholder theory, and the corporate objective function. European Financial Management Review, 14(3), 8-21.

Johnsen, A. (2001). Balanced scorecard: Theoretical perspectives and public management implications. Managerial Auditing Journal, 16(6), 319-330.

Jusoh, R., \& Parnell, J. A. (2008). Competitive strategy and performance measurement in the Malaysian context: An exploratory study. Management Decision, 46(1), 5-31.

Kaplan, R. S., \& Norton, D. P. (1992). The balanced scorecard measures that drive performance. Harvard Business Review, 70(1), 71-79.

Kaplan, R. S., \& Norton, D. P. (1996a). The balanced scorecard translating strategy into action. Boston, MA: Harvard Business School Press.

Kaplan, R. S., \& Norton, D. P. (1996b). Linking the balanced scorecard to a strategy. California Management Review, 39(1), 53-79.

Kaplan, R. S., \& Norton, D. P. (1996c). Using the balanced scorecard as a strategy management system. Harvard Business Review, 74(1), 75-85.

Kaplan, R. S., \& Norton, D. P. (2001). Transforming balanced scorecard from performance measurement to strategic management: Part I. Accounting Horizons, 15(1), 87-104.

Kartalis, N., Velentzas, J., \& Broni, G. (2013). Balance scorecard and performance measurement in a Greek industry. Procedia Economics and Finance, 5(0), 413422. doi: http://dx.doi.org/10.1016/S22125671(13)00049-X

Moufty, S. (2009). The role of balanced scorecard in UK banks as a performance measurement. BBS Doctoral Symposium, 23(24 (2009)), 1-8.

Niven, P. R. (2002). Balanced scorecard step-by-step: Maximizing performance and maintaining results. New York, NY: John Wiley \& Sons, Inc.

Pandey, I. M. (2005). Balanced scorecard: Myth and reality. Vikalpa, 30(1), 51-66. 
Tran Trung TUAN/ Journal of Asian Finance, Economics and Business Vol 7 No 1 (2020) 71-79

Stede, W. A. V. D., Chow, C. W., \& Lin, T. W. (2006). Strategy, choice of performance measures, and performance. Behavioral Research in Accounting, 18(2006), 185-205.

Sureshchandar, G., Rajendran, C., \& Anantharaman, R. (2002). Determinants of customer perceived service quality: A confirmatory factor analysis approach. Journal of Services Marketing, 16(1), 9-34.
Brignall, T. J., Fitzgerald, L., Johnston, R., \& Silvestro, R. (1991). Performance measurement in service businesses. Management Accounting, Nov.1991(10), 34-49.

Zahirul, H., \& Wendy, J. (2000). Linking balanced scorecard measures to size and market factors: Impact on organizational performance. Journal of Management Accounting Research, 12, 1-17. 